\title{
COMMENTARY
}

\section{Surfactant protein genetics in community-acquired pneumonia: balancing the host inflammatory state}

\author{
Joanna Floros ${ }^{* 1,2}$ and Neal J Thomas ${ }^{1,3}$
}

See related research by García-Laorden et al., http://ccforum.com/content/15/1/R57

\begin{abstract}
Community-acquired pneumonia is a common disease. Abnormalities in the first step of host defense may severely compromise subsequent steps of successfully combating infections. In the previous issue of Critical Care, García-Laorden and colleagues reported genetic associations between single-nucleotide polymorphisms and haplotypes of the surfactant proteins with susceptibility, severity, and outcome of community-acquired pneumonia. Although the limited information shows regulatory differences among variants, it is currently unknown how the difference in surfactant protein A genotypes in this and other studies affects the individual's phenotype. The lung is continually exposed to a host of irritants yet maintains health. It is plausible that, under physiologic conditions, surfactant protein $\mathrm{A}$, in addition to having a dominant effect on anti-inflammatory processes, mediates a low level of proinflammatory processes that are essential for the health of the lung. Understanding the maintenance of the balance of the inflammatory state may be one of the keys to understanding pulmonary disease progression.
\end{abstract}

Community-acquired pneumonia (CAP) is a common cause of intensive care unit admission and can lead to acute respiratory distress syndrome (ARDS) and multiple organ dysfunction syndrome (MODS), major causes of mortality after CAP. At present, treatment is supportive, and determining which patients will have a higher likelihood of disease severity is not possible. In the previous issue of Critical Care, García-Laorden and colleagues [1] attempted to begin to unravel the complex gene-environment interactions in a syndrome whose progression is

*Correspondence: jfloros@psu.edu

'Department of Pediatrics, Center for Host defense, Inflammation, and Lung Disease (CHILD) Research, 500 University Drive, H085, Hershey, PA 17033, USA Full list of author information is available at the end of the article felt to be multifactorial. The authors should be commended for this work. Determining who is more likely or less likely to develop CAP, develop ARDS and MODS after CAP, or die from this infection is an important endeavor. Innate immunity clearly plays an important role. Abnormalities in the first step of host defense may severely compromise subsequent steps of successfully combating infections. The hope is that novel therapies can target these most susceptible patients, even before the downstream clinical events fully develop. However, before this next step may be taken, certain limitations of the present study require further work. Of paramount importance is whether the results of this study are generalizable to populations other than a relatively homogeneous Spanish Caucasoid group. Before studies such as the present one can be universally accepted, they require validation in a distinct group of individuals.

The authors reported genetic associations between single-nucleotide polymorphisms of the surfactant proteins, as well as haplotypes encompassing these genes, with susceptibility, severity, and outcome of CAP. Several associations remain significant even after stringent multiple comparison corrections. These findings are not surprising, given the important role of innate immunity in host defense. There are a significant number of studies in which associations of genetic variants of surfactant protein A (SFTPA) 1, SFTPA2, and SFPD with disease susceptibility have been identified and these cover the entire life span, from birth and childhood through adulthood [2]. Owing to their extensive complexity, the SFTPA genes, in particular, provide a good model with which to study disease susceptibility and severity. The extensive complexity makes it a challenge to fully understand and interpret any associations made (including those in the present study) but at the same time provides an opportunity to learn about disease pathogenesis. At present, although some insight into mechanisms underlining differential regulation of the different variants in response to various insults such as bacteria or oxidative stress (or both) has been gained [37], this knowledge is still in the early stages and is insufficient for assessing how the difference in SFTPA 
genotypes in this and other studies affects the individual's phenotype or for contemplating therapeutic points of interventions based on SFTPA genotype.

The authors clearly appreciate the dual role of SP-A, its ability to promote proinflammatory processes in response to pathogens or other insults, and its ability, under 'basal' conditions, to suppress nuclear factor-kappa-B (NF-kB) activation and inflammation. However, we would like to raise the point that even under 'basal' physiologic conditions (that is, in the absence of an overbearing pathogen load), the lung is exposed daily to hundreds of thousands of irritants (for example, bacteria, viruses, pollen, and toxins) yet the lung maintains a healthy status. We would like to put forward the idea that, under physiologic conditions, SP-A, in addition to having a dominant effect on anti-inflammatory processes, mediates a low level of proinflammatory processes that are essential for the health of the lung. Several in vitro studies have shown the ability of SP-A, in the absence of pathogens, to generate a low-level proinflammatory response [8-16]. It is possible that the SP-A-mediated proinflammatory activity (high or low levels) is 'contextdependent' and reflects the magnitude of the threat. Whether the mechanisms of this proinflammatory activity at low physiologic level overlap with or are completely different from those of the high-level activity generated in the presence of high-load pathogens or other irritants remains to be determined.

The collective data, including the data from this study of the association of surfactant proteins with disease risk, beg for a better understanding of the functional and regulatory differences among common and rare SPFTA variants. Understanding the underlining regulatory control differences among SPFTA variants could identify points amenable to therapeutic intervention, which could lead to treatment options that are truly individualized to the patient's genotype. The ultimate goals, once the mechanisms by which these genetic differences influence outcome have been determined, would most likely be to develop novel technologies that will allow the addition of SP-A (or even a specific SP-A variant) and SP-D into exogenous surfactant preparations (similar to SP-B and SP-C formulations that are presently being tested) and to target a group of individuals based on both their etiology of lung disease (that is, infection) and their individual genotype.

\section{Abbreviations}

ARDS, acute respiratory distress syndrome; CAP, community-acquired pneumonia; MODS, multiple organ dysfunction syndrome; SFTPA, surfactant protein $\mathrm{A}$.

\section{Competing interests}

NJT serves as a consultant and is a member of the Advisory Board for Discovery Laboratories, Warrington, PA. JF has no competing interests.

\section{Acknowledgments}

This work was supported by National Institutes of Health grant HL34788.

\section{Author details}

'Department of Pediatrics, Center for Host defense, Inflammation, and Lung Disease (CHILD) Research, 500 University Drive, H085, Hershey, PA 17033, USA. 2Department of Obstetrics and Gynecology, College of Medicine, Pennsylvania State University College of Medicine, 500 University Drive, H085, Hershey, PA 17033, USA. ${ }^{3}$ Department of Public Health Sciences, College of Medicine, Pennsylvania State University College of Medicine, 500 University Drive, H085, Hershey, PA 17033, USA.

\section{Published: 21 April 2011}

\section{References}

1. García-Laorden MI, Rodríguez de Castro F, Solé-Violán J, Rajas O, Blanquer J, Borderías L, Aspa J, Briones ML, Saavedra P, Marcos-Ramos JA, González-Quevedo N, Sologuren I, Herrera-Ramos E, Ferrer JM, Rello J, Rodríguez-Gallego C: Influence of genetic variability at the surfactant proteins $A$ and $D$ in community-acquired pneumonia: a prospective, observational, genetic study. Crit Care 2011, 15:R57.

2. Silveyra P, Floros J: Genetic variant associations of human SP-A and SP-D with acute and chronic lung disease. Front Biosci, in press.

3. Wang G, Guo X, Silveyra P, Kimball SR, Floros J: Cap-independent translation of human SP-A 5'-UTR variants: a double-loop structure and cis-element contribution. Am J Physiol Lung Cell Mol Physiol 2009, 296:L635-647.

4. Wang G, Guo X, Floros J: Differences in the translation efficiency and mRNA stability mediated by $5^{\prime}$-UTR splice variants of human SP-A1 and SP-A2 genes. Am J Physiol Lung Cell Mol Physio/ 2005, 289:L497-L508.

5. Wang G, Guo X, Floros J: Human SP-A 3'-UTR variants mediate differential gene expression in basal levels and in response to dexamethasone. Am J Physiol Lung Cell Mol Physiol 2003, 284:L738-748.

6. Hoover RR, Thomas KH, Floros J: Glucocorticoid inhibition of human SP-A1 promoter activity in NCl-H441 cells. Biochem J 15 1999, 340 (Pt 1):69-76.

7. Silveyra P, Wang G, Floros J: Human SP-A1 (SFTPA1) variant-specific $3^{\prime}$ UTRs and poly $(A)$ tail differentially affect the in vitro translation of a reporter gene. Am J Physiol Lung Cell Mol Physiol 2010, 299:L523-534

8. Condon JC, Jeyasuria P, Faust JM, Mendelson CR: Surfactant protein secreted by the maturing mouse fetal lung acts as a hormone that signals the initiation of parturition. Proc Natl Acad Sci U S A 2004, 101:4978-4983.

9. Wang G, Phelps DS, Umstead TM, Floros J: Human SP-A protein variants derived from one or both genes stimulate TNF-alpha production in the THP-1 cell line. Am J Physiol Lung Cell Mol Physio/ 2000, 278:L946-954.

10. Wang G, Umstead TM, Phelps DS, Al-Mondhiry H, Floros J: The effect of ozone exposure on the ability of human surfactant protein A variants to stimulate cytokine production. Environ Health Perspect 2002, 110:79-84

11. Huang W, Wang G, Phelps DS, Al-Mondhiry H, Floros J: Combined SP-Ableomycin effect on cytokines by THP-1 cells: impact of surfactant lipids on this effect. Am J Physiol Lung Cell Mol Physiol 2002, 283:L94-L102.

12. Huang W, Wang G, Phelps DS, Al-Mondhiry H, Floros J: Human SP-A genetic variants and bleomycin-induced cytokine production by THP-1 cells: effect of ozone-induced SP-A oxidation. Am J Physiol Lung Cell Mol Physiol 2004, 286:L546-553.

13. Janic B, Umstead TM, Phelps DS, Floros J: Modulatory effects of ozone on THP-1 cells in response to SP-A stimulation. Am J Physiol Lung Cell Mol Physio/ 2005, 288:L317-325.

14. Song M, Phelps DS: Interaction of surfactant protein A with lipopolysaccharide and regulation of inflammatory cytokines in the THP-1 monocytic cell line. Infect Immun 2000, 68:6611-6617.

15. Song M, Phelps DS: Comparison of SP-A and LPS effects on the THP-1 monocytic cell line. Am J Physiol Lung Cell Mol Physiol 2000, 279:L110-117.

16. Guillot L, Balloy V, McCormack FX, Golenbock DT, Chignard M, Si-Tahar M: Cutting edge: the immunostimulatory activity of the lung surfactant protein-A involves Toll-like receptor 4. J Immunol 2002, 168:5989-5992.

doi:10.1186/cc10115

Cite this article as: Floros J, Thomas NJ: Surfactant protein genetics in community-acquired pneumonia: balancing the host inflammatory state. Critical Care 2011, 15:156. 